\title{
Temperature Dependence of Intrinsic Membrane Properties and Synaptic Potentials in Hippocampal CA1 Neurons In Vitro ${ }^{1}$
}

\author{
SCOTT M. THOMPSON, ${ }^{2}$ LEONA M. MASUKAWA, ${ }^{3}$ AND DAVID A. PRINCE \\ Department of Neurology, Stanford University Medical Center, Stanford, California 94305
}

\begin{abstract}
The temperature dependence of intrinsic membrane conductances and synaptic potentials in guinea pig hippocampal CA1 pyramidal neurons were examined in vitro as they were cooled from $37^{\circ} \mathrm{C}$ to between 33 and $27^{\circ} \mathrm{C}$. Cooling reversibly increased resting input resistance in a voltage-independent manner $\left(Q_{10}=0.58\right.$ to 0.75$)$. The amplitude and duration of orthodromically evoked action potentials were increased by cooling $\left(Q_{10}=0.87\right.$ and 0.52 to 0.53 , respectively), whereas the maximum rates of rise and fall were reduced $\left(Q_{10}=1.27\right.$ to 1.49 and 2.19 to 2.44 , respectively). The amplitude and duration of the afterhyperpolarization which follows a directly evoked train of action potentials were substantially increased at low temperatures. It is possible to attribute this increase to an augmentation of $\mathrm{Ca}^{2+}$ influx during the train and also to a slowing of $\mathrm{Ca}^{2+}$ removal from the cytoplasm. Spike frequency adaptation during prolonged depolarizing pulses was enhanced at low temperatures. In addition, there was a decrement in spike amplitude during the train of action potentials. These observations all suggest an increase in $\mathrm{Ca}^{2+}$. activated $\mathrm{K}^{+}$conductance at low temperature. A late, slow, hyperpolarizing synaptic potential in response to orthodromic stimulation became apparent at low temperature. This potential had an apparent reversal potential more negative than the early inhibitory postsynaptic potential, suggesting that it was mediated by a $\mathrm{K}^{+}$conductance, possibly activated by $\mathrm{Ca}^{2+}$ influx. We conclude that reductions in temperature of as little as 5 to $10^{\circ} \mathrm{C}$ from normal can significantly alter the intrinsic and synaptic physiology of hippocampal neurons and should, therefore, be considered an important variable in in vitro brain slice experiments.
\end{abstract}

Use of the in vitro brain slice technique has greatly enhanced our ability to study the physiology of neurons in the central nervous system. One of the advantages of this technique is the ability to quickly and easily control and alter the environment surrounding these neurons. Unfortunately, consistent control recording conditions have not been adopted (Alger et al., 1984), and few studies

Received July 2, 1984; Revised September 17, 1984; Accepted September 20, 1984

\footnotetext{
'We gratefully acknowledge the secretarial assistance of Cheryl Joo, and the programming and technical support of Jay Kadis. This work was supported by National Institutes of Health Grants NS 12151 and NS 06477 from the National Institute of Neurological and Communicative Disorders and Stroke.

${ }^{2}$ To whom correspondence should be addressed.

${ }^{3}$ Current address: Section on Neuroanatomy, Yale University School of Medicine, New Haven, CT 06510.
}

have examined the effects of varying these conditions on the physiology of neurons. Perhaps the greatest variability between laboratories exists in the choice of experimental temperature. Brain slice tissue is routinely maintained for experimentation in vitro at a variety of temperatures ranging from $23^{\circ} \mathrm{C}$ to $37^{\circ} \mathrm{C}$ (e.g., Schwartzkroin, 1975; Nicoll and Alger, 1981a; Halliwell and Adams, 1982). Reduced temperature may enhance slice viability and increase the dissolved oxygen content of the bathing medium, allowing slices to be totally submerged (Harvey et al., 1974). In addition, slowing of ion channel kinetics at low temperature may facilitate use of the single-electrode voltage clamp technique (Johnston and Brown, 1983). In view of the large temperature dependence of enzymatic reaction rates and ion channel kinetics, it seemed likely that significant alterations in neuronal physiology could result from maintenance in vitro at reduced temperatures. Therefore, we examined the effects of cooling CA1b hippocampal pyramidal cells of the guinea pig from $37^{\circ} \mathrm{C}$ to between 33 and $27^{\circ} \mathrm{C}$ and found distinct changes in the electrical properties and synaptic responses of these neurons within this range. An abstract of some of these results has been presented (Masukawa et al., 1984).

\section{Materials and Methods}

Adult guinea pigs were decapitated and their brains were rapidly removed and placed in ice-cold perfusion medium. The hippocampus was dissected free and $400-\mu \mathrm{m}$-thick transverse slices were obtained using a Mcllwain tissue chopper. The slices were immediately placed in the recording chamber (Schwartzkroin, 1975) at the gas-saline interface and were allowed to remain for 1 to $2 \mathrm{hr}$ at $37^{\circ} \mathrm{C}$ before experimentation began. The slices were superfused with medium containing (in millimolar concentration): $\mathrm{NaCl}, 124$ $\mathrm{KCl}, 5 ; \mathrm{NaHCO}_{3}, 26 ; \mathrm{NaH}_{2} \mathrm{PO}_{4}, 1.25 ; \mathrm{MgSO}_{4}, 2 ; \mathrm{CaCl}_{2}, 2.5$; dextrose, 10 . The $\mathrm{pH}$ was maintained at 7.4 with $95 \% \mathrm{O}_{2} / 5 \% \mathrm{CO}_{2}$ and did not vary in the temperature range examined. Intracellular recordings were made from $\mathrm{CA} 1 \mathrm{~b}$ pyramidal neurons, penetrated with 30 - to 100 -megohm microelectrodes filled with $4 \mathrm{~m}$ potassium acetate. Neurons accepted for study had stable resting membrane potentials of greater than $-55 \mathrm{mV}$ at $37^{\circ} \mathrm{C}$ (mean $=-63.9$ $\pm 9.4 \mathrm{mV}, n=23$ ), overshooting action potentials, and fired repetitively during depolarizing current pulses. Steady-state current-voltage plots were obtained from each cell by measuring the voltage deflections ( $\Delta V$ produced at the end of $120-\mathrm{msec}$ current pulses of varying amplitude $(\Delta /)$ passed through the recording electrode via an active bridge circuit. Neuronal input resistance $\left(R_{N}\right)$ was determined from the slope of the linear, subthreshold portion of the plot. Apparent input resistance was determined by dividing the amplitude of the voltage deflection by the amplitude of the current pulse $(\Delta V / \Delta /)$. Synaptic potentials were evoked by brief $(0.1 \mathrm{msec})$ current pulses delivered through sharpened, bipolar tungsten electrodes placed in stratum radiatum. Data were stored on magnetic tape $(0$ to $5 \mathrm{kHz})$ for later analysis on a MINC-23 computer.

The effects of cooling were examined in two ways. First, data were collected from two populations of cells, one at $37^{\circ} \mathrm{C}$ and another at $27^{\circ} \mathrm{C}$. Intracellular recordings were made at $37^{\circ} \mathrm{C}$; then, the slices were cooled to $27^{\circ} \mathrm{C}$ and allowed to equilibrate for $30 \mathrm{~min}$ to $1 \mathrm{hr}$. Second, single-cell recordings were maintained while cells were cooled from $37^{\circ} \mathrm{C}$ to between 
TABLE I

Cellular parameters of $\mathrm{CA} 1$ pyramidal cells at $37^{\circ} \mathrm{C}$ or $27^{\circ} \mathrm{C}$

Values are presented as mean \pm standard deviation with the number given in parentheses. Significance was measured with the two-tailed Student's $t$ tesl.

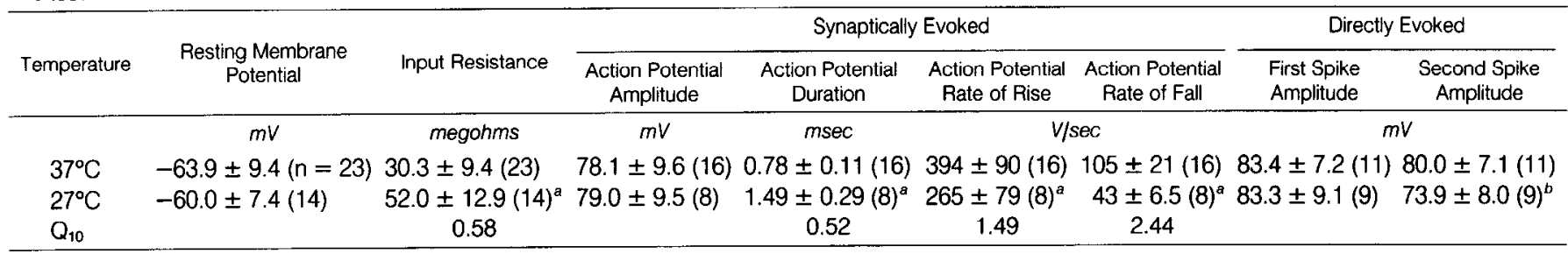

${ }^{a} p<0.001$

${ }^{\circ} p<0.02$.

Figure 1. Effects of cooling on the current-voltage relationship of a single, representative CA1 cell. Data were obtained by measuring voltage deflection from rest $\left(\Delta V_{m}\right)$ produced at the end of 120 -msec current pulses of varying amplitude and polarity $(\Delta /)$ passed through the recording electrode via an active bridge circuit. $A_{1}$ Current versus voltage at $37^{\circ} \mathrm{C}, 27^{\circ} \mathrm{C}$, and upon rewarming to $31^{\circ} \mathrm{C}$. Resting potentials were -67 $\mathrm{mV}$ at $37^{\circ} \mathrm{C},-69 \mathrm{mV}$ at $27^{\circ} \mathrm{C}$, and $-71 \mathrm{mV}$ at $31^{\circ} \mathrm{C}$. Slope resistance increased from 39 megohms at $37^{\circ} \mathrm{C}$ to 74 megohms at $27^{\circ} \mathrm{C}$ and partially recovered to 62 megohms upon rewarming to $31^{\circ} \mathrm{C} . B$, In the same cell as in $A$, apparent resistance $\left(\Delta V_{m} / \Delta /\right)$ was calculated from each pulse and is plotted versus $\Delta V_{m}$. Note that the increase in resistance was relatively uniform at all $V_{m} \mathrm{~s}$.
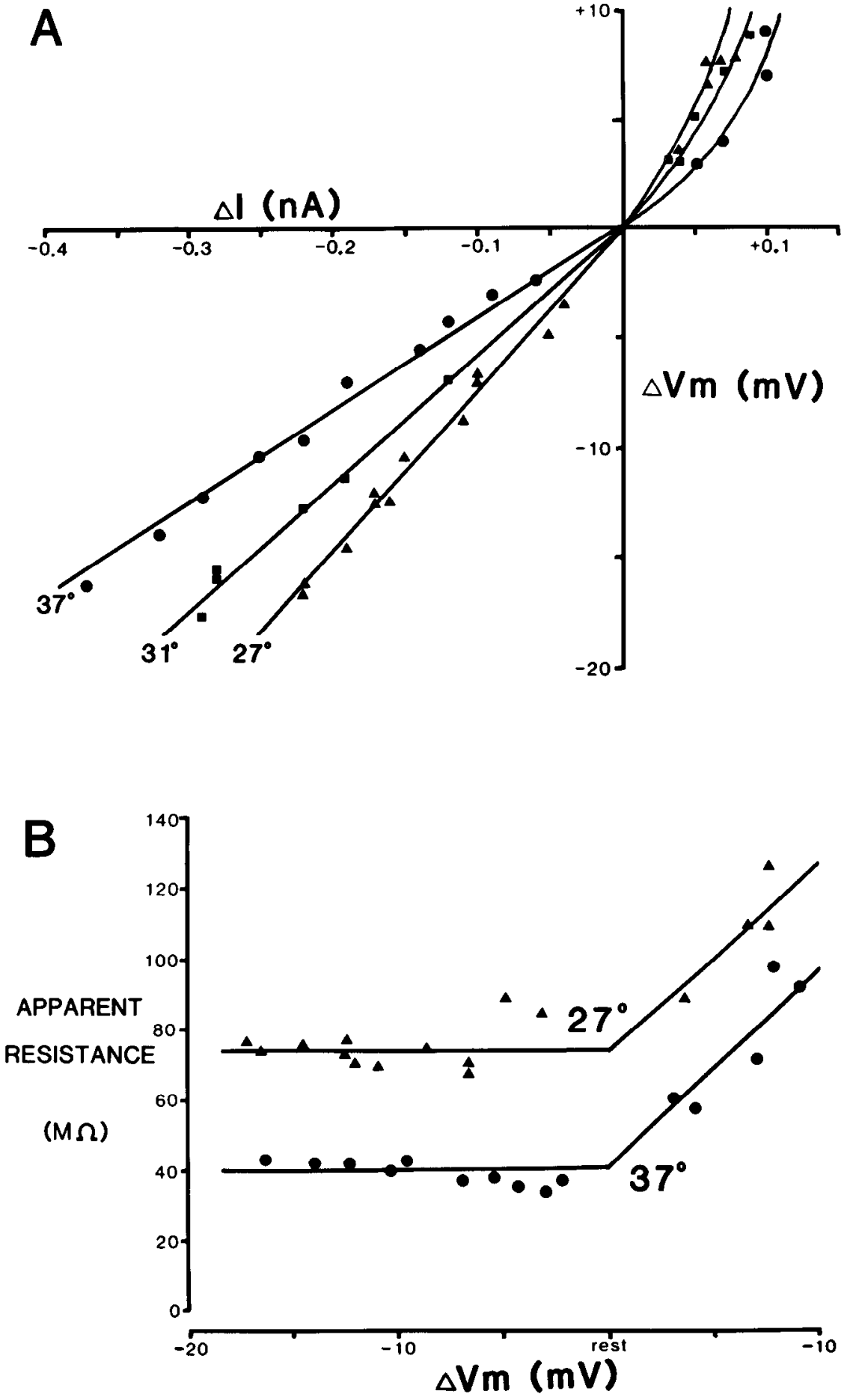


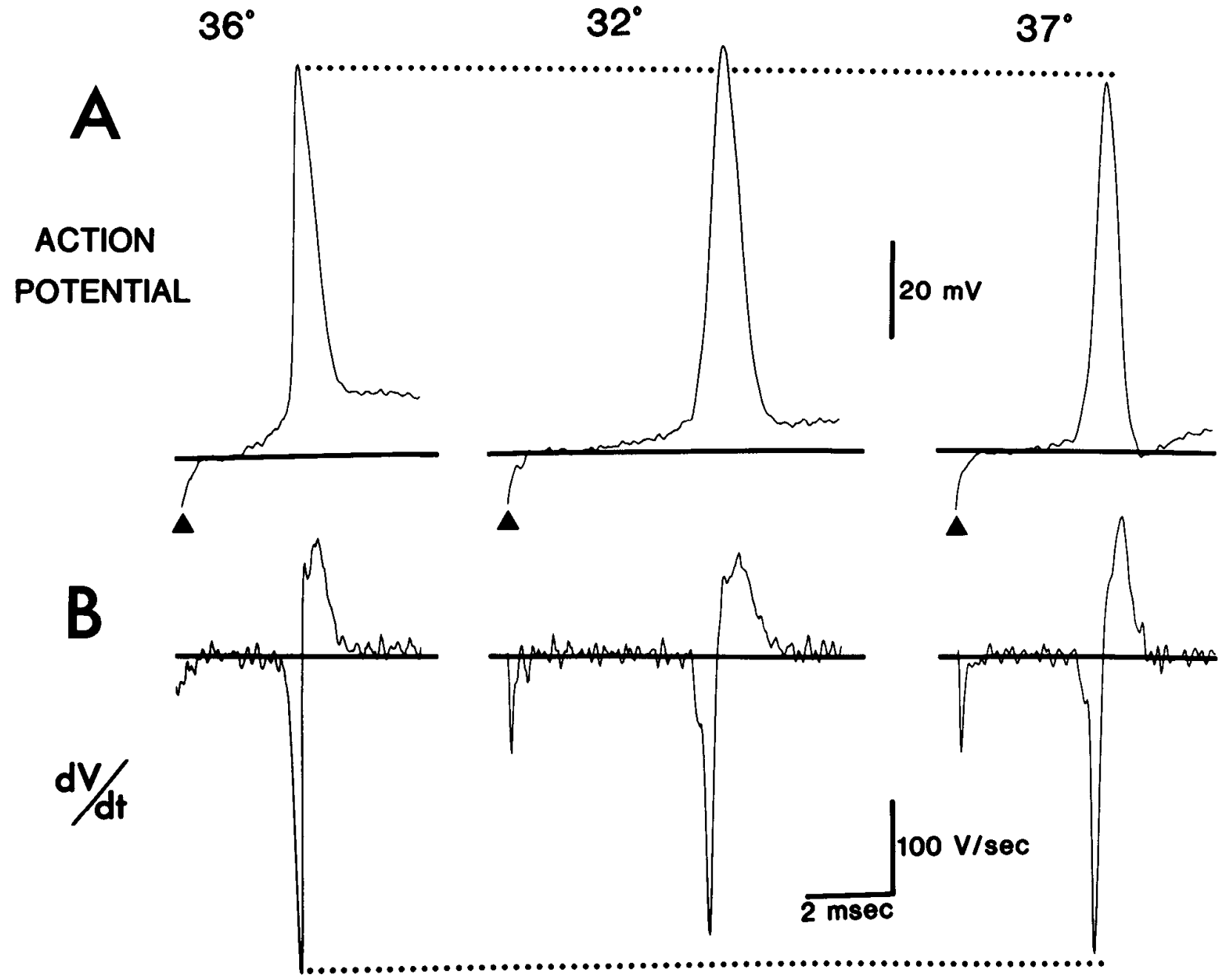

Figure 2. Effects of cooling on orthodromically evoked action potentials of a single cell at identical $V_{m}(-70 \mathrm{mV})$ recorded at $36^{\circ} \mathrm{C}, 32^{\circ} \mathrm{C}$, and upon rewarming to $37^{\circ} \mathrm{C}$. A, Cooling the cell increased the amplitude and duration (measured at half-maximal amplitude) of the action potential $5 \%$ and $20 \%$, respectively. Stimulus artifacts are indicated by solid triangles. $B$, Computer-differentiated records of the same action potentials. The maximum rates of rise (downward deflection) and fall (upward deflection) were reduced $11 \%$ and $14 \%$, respectively, by cooling from 37 to $31^{\circ} \mathrm{C}$. These effects were reversed upon rewarming.

33 and $27^{\circ} \mathrm{C}$ at a rate of 0.2 to $1^{\circ} \mathrm{C} / \mathrm{min}$ by passing the saline inflow over a Peltier device (Borg-Warner model 930-17). The effects of cooling could be reversed when the cells were rewarmed by reversing the direction of the current flow across the Peltier device. Temperature was continuously monitored at the gas-saline interface with a microthermistor $(0.4 \mathrm{~mm}$, Bailey Instruments $\mathrm{Co}$.). Similar results were obtained from both sets of experiments. Estimates of the temperature coefficients $\left(Q_{10}\right)$ were made to facilitate comparisons with previously reported values of temperature dependence. For a given parameter $(X)$ measured at two temperatures $\left(T_{1}\right.$ and $\left.T_{2}\right)$ :

$$
Q_{10}=\left(X_{2} / X_{1}\right)^{10 / T_{2}-T_{1}}
$$

\section{Results}

The membrane properties of two populations of cells recorded at either 37 or $27^{\circ} \mathrm{C}$ are compared in Table I. The average resting membrane potential $\left(V_{m}\right)$, determined by measuring the amplitude of the deflection obtained by withdrawing the electrode from the cell, was not significantly different at these two temperatures. The average $R_{N}$, however, increased significantly from $30.3 \pm 9.4 \mathrm{meg}$ ohms at $37^{\circ} \mathrm{C}$ to $52.0 \pm 12.9$ megohms at $27^{\circ} \mathrm{C}\left(p<0.001, Q_{10}=\right.$ 0.58 ). Comparable increases in $R_{N}$ were also observed in single cells as they were cooled from $37^{\circ} \mathrm{C}$ to between 33 and $27^{\circ} \mathrm{C}$ (mean $Q_{10}=0.75 \pm 0.2$ ). Current-voltage plots for a single representative cell as it was cooled from 37 to $27^{\circ} \mathrm{C}$ and then warmed back up to $31^{\circ} \mathrm{C}$ are shown in Figure $1 A$. In this cell the $R_{N}$ increased from 39 megohms at $37^{\circ} \mathrm{C}$ to 74 megohms at $27^{\circ} \mathrm{C}$. This increase was partially reversed by rewarming the cell to $31^{\circ} \mathrm{C}$. Plots of apparent resistance versus $V_{m}(\mathrm{Fig} .1 B)$ show that the resistance increased equally at all $V_{m} s$, suggesting that cooling decreases a voltageindependent resting conductance. In addition, this indicates that anomalous inward rectification, the apparent increase in input resistance due to activation of subthreshold inward current at $V_{m} s$ depolarized from rest (Hotson et al., 1979), was not significantly altered.

Temperature has been known to affect the kinetics of voltagedependent ion channels underlying the action potential in a variety of species and was accounted for in the formulation of the HodgkinHuxley equations (Hodgkin and Huxley, 1952). The temperature dependence of several parameters of the action potential was examined in single cells as they were cooled. Action potentials were evoked with orthodromic synaptic stimulation at identical $V_{m} s$. Both the amplitude, measured from the base of the action potential, and the duration, measured at half-maximal amplitude, increased as cells were cooled (mean $Q_{10}=0.87 \pm 0.04$ and $0.53 \pm 0.15$, respectively; $n=6$ ) (Fig. 2A). Computer differentiated records of these action potentials indicated that cooling reduces the maximum rates of rise and fall of the action potential (mean $Q_{10}=1.27 \pm 0.34$ and $2.19 \pm$ 1.03, respectively; $n=6$ ) (Fig. $2 B$ ). Changes in action potential parameters of a similar magnitude were observed in the population 
$36^{\circ}$

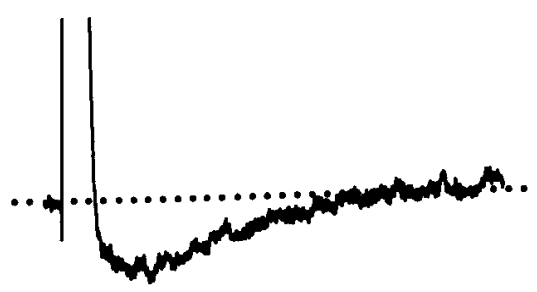

$32^{\circ}$

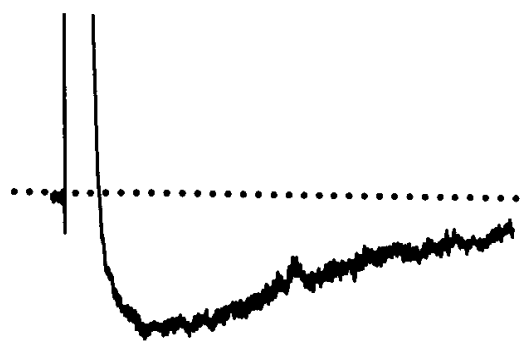

$37^{\circ}$

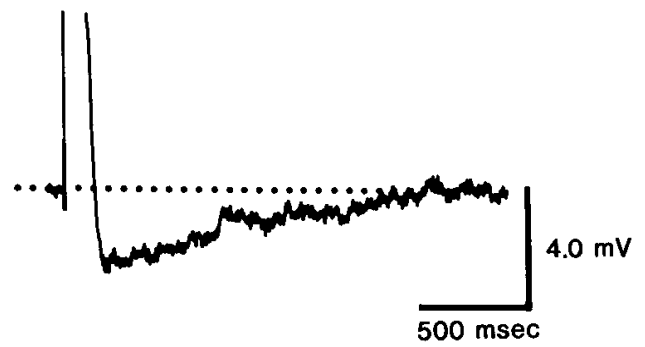

Figure 3. Effects on cooling on the AHP which follows a burst of six action potentials evoked by 120-msec depolarizing current pulses in a single cell. Note the reversible increase in the size of the AHP at low temperature. Action potentials have been amputated due to high gain.

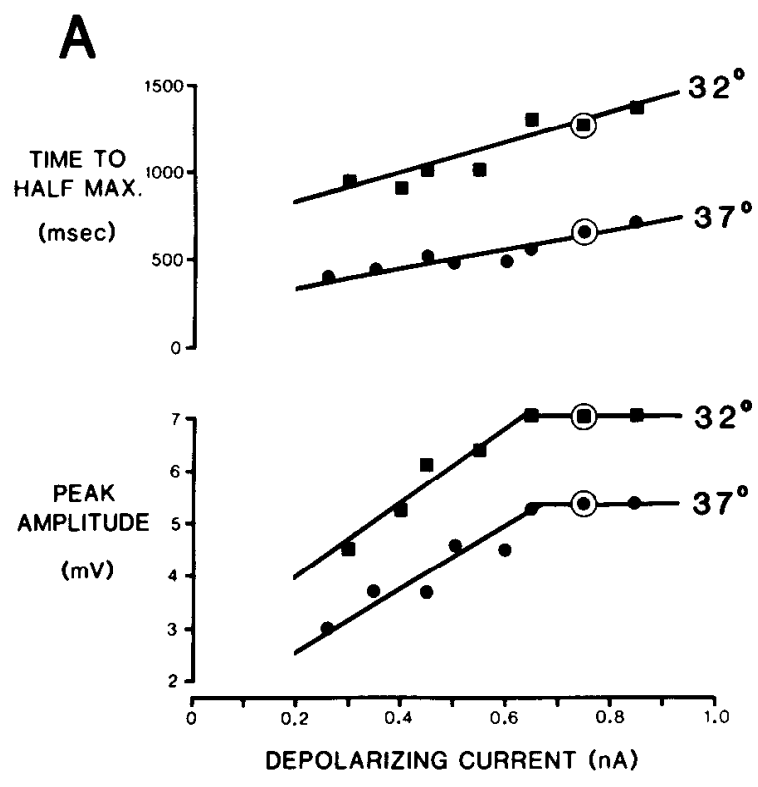

B

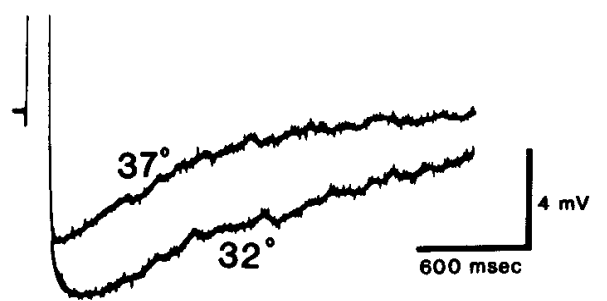

C

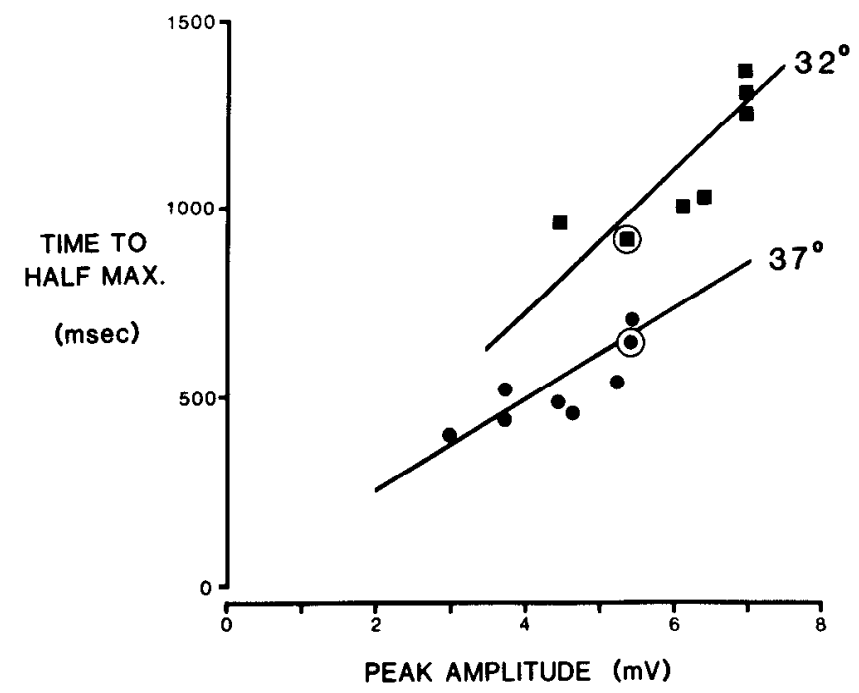

D

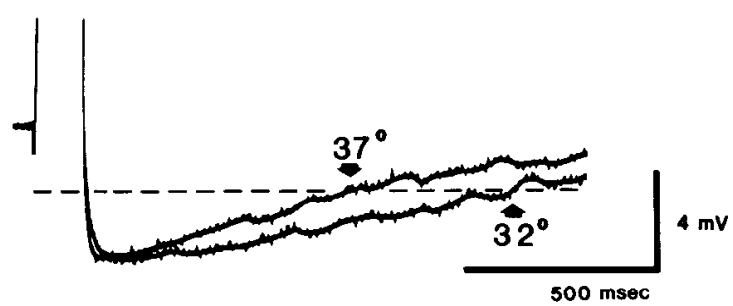

Figure 4. Effects of cooling on AHP which follows bursts of action potentials evoked by $120-\mathrm{msec}$ depolarizing current pulses of varying amplitude in a single cell at 37 and $32^{\circ} \mathrm{C}$. DC current was used to return the cell to its original rest $V_{m}(-57 \mathrm{mV})$. A, Plots of peak AHP amplitude and the time needed for the AHP to decay to half-maximal amplitude, an indicator of the decay rate, for varying amplitude current pulses. Note the large increase in amplitude and duration of the AHP for any given current intensity at low temperature. $B$, AHPs evoked by 0.75 -nA current pulse (circled symbols in $A$ ) at 37 and $32^{\circ} \mathrm{C}$. Action potentials have been amputated due to high gain. $C$. Plot of peak AHP amplitude versus time to half-maximal amplitude from the same cell as in $A$. Note the large increase in the duration for AHPs of all amplitudes. D. AHPs of equal amplitude (circled symbols in $C$ ) at 37 and $32^{\circ} \mathrm{C}$. The dashed line indicates half-maximal amplitude. Action potentials have been amputated due to high gain.

of cells at $27^{\circ} \mathrm{C}$ with the exception of the increased action potential amplitude (Table I). The small increase in action potential amplitude with cooling may have been obscured by the variance of the pooled data, whereas data from single cells are more sensitive to small changes.

A striking change resulting from cooling was the increase in the amplitude and duration of the afterhyperpolarization (AHP) which followed a directly evoked train of spikes (Fig. 3) (10 of 10 cells). The increase in the size of the AHP was readily reversed upon rewarming. This afterpotential has been shown by several investigators to be the result of a $\mathrm{Ca}^{2+}$-activated $\mathrm{K}^{+}$conductance (Hotson et al., 1977; Alger and Nicoll, 1980; Hotson and Prince, 1980; Schwartzkroin and Stafstrom, 1980). Two partially dissociable processes, which influence the amplitude and duration of the AHP, might be affected by cooling: the amount of $\mathrm{Ca}^{2+}$ influx, and its rate of removal from the cytoplasm. This can be examined by comparing the AHPs which follow trains of action potentials produced by 120 msec depolarizing current pulses of varying amplitude. In Figure 4A, both the peak amplitude and the duration (measured as the time of decay from peak to half-maximal amplitude) of the AHPs are compared at $37^{\circ} \mathrm{C}$ and at $32^{\circ} \mathrm{C}$ in a single cell. For any given current intensity, both the amplitude and the duration of the AHP were 

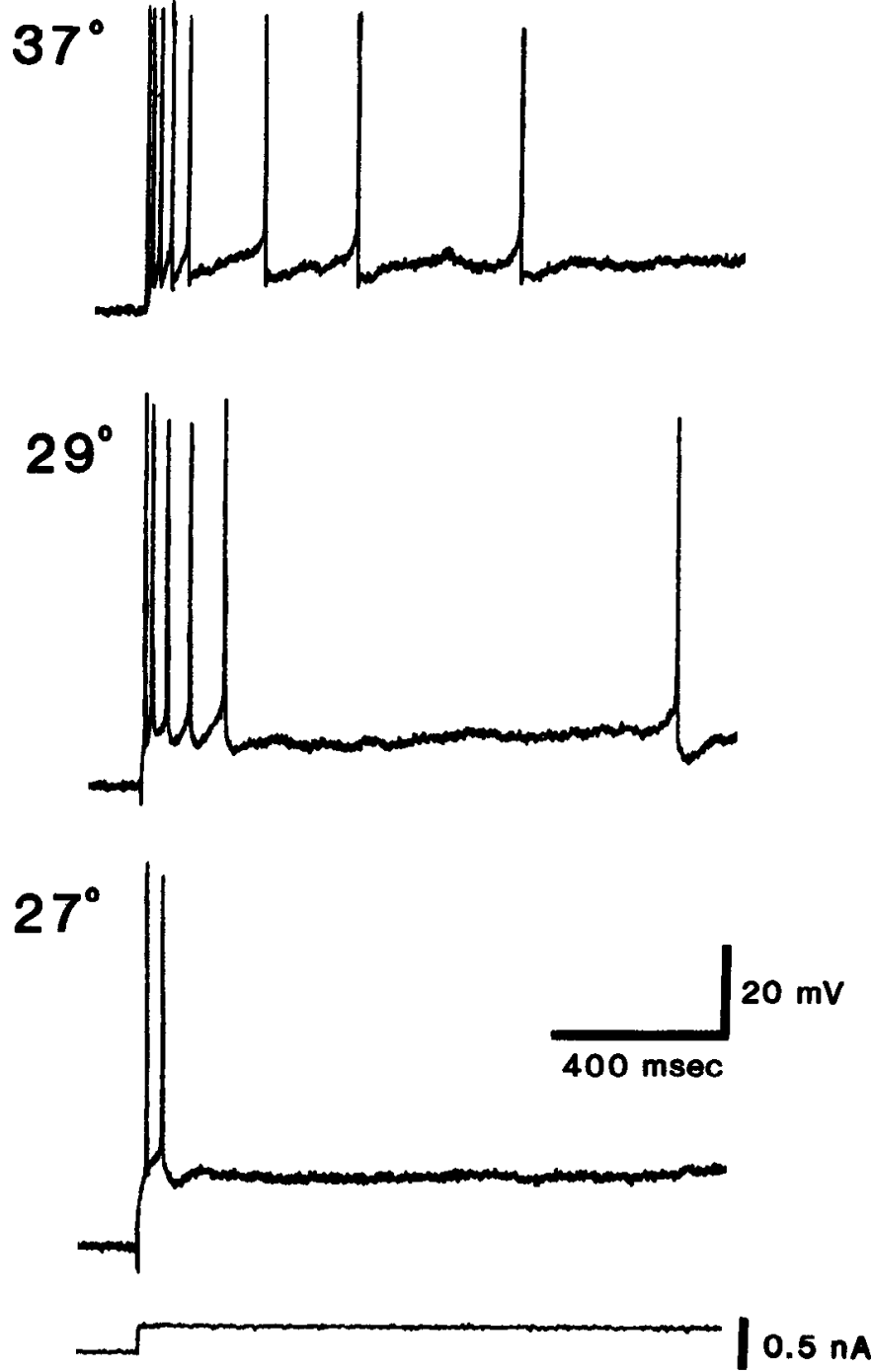

Figure 5. Effect of cooling on spike frequency adaptation. Shown are responses of a single cell to prolonged step depolarization produced by a 0.3-nA current pulse at $37^{\circ}, 29^{\circ}$, and $27^{\circ} \mathrm{C}$. Note the progressive inability of the neuron to maintain discharge throughout the depolarizing pulse.

increased at low temperature (Fig. $4 B$ ). The increase in the duration of the AHP appeared to result from a reduction in its rate of decay. When the duration of the AHP is compared to its initial amplitude (Fig. 4C), it can be seen that, for any given peak amplitude of the AHP, the time to half-maximum is greatly increased at low temperature (Fig. 4D). Thus, cooling reduced the rate of decay of the AHP as well as increased its amplitude.

Hippocampal neurons in vivo and in vitro at $37^{\circ} \mathrm{C}$ respond to prolonged depolarizing step currents with an initial, rapid train of action potentials followed by maintained firing at a reduced rate (Spencer and Kandel, 1961; Schwartzkroin, 1977). This decrease in firing frequency has been termed "spike frequency adaptation" and is believed to result from activation of the $\mathrm{Ca}^{2+}$-activated $\mathrm{K}^{+}$conductance (Madison and Nicoll, 1982). Spike frequency adaptation was found to be greatly enhanced at lower temperatures (Fig. 5); often the neurons did not fire any action potentials after the initial brief train. In addition, a large decrease in the amplitude of the succeeding action potentials in a directly evoked train of spikes is apparent at low temperature (Fig. 6, Table 1). This decrease could be caused by an increase in an outward current, such as $\mathrm{Ca}^{2+}$. activated $\mathrm{K}^{+}$current, during the train. Opposite effects were seen in cells which were warmed from low temperature (not shown). Taken together, these lines of evidence suggest a significant increase in $\mathrm{Ca}^{2+}$-activated $\mathrm{K}^{+}$current at lower temperatures.

Synaptic responses were also qualitatively altered by reducing the temperature. At $37^{\circ} \mathrm{C}$, orthodromic stimulation of stratum radiatum evoked an excitatory postsynaptic potential (EPSP), which triggered an action potential at sufficient stimulus intensities, followed by a large, monophasic inhibitory postsynaptic potential (IPSP) (Fig $7 A$, first trace). At cooler temperatures the peak amplitude of the early IPSP was decreased ( 8 of 9 cells) and a second, later hyperpolarizing potential became apparent ( 5 of 9 cells; Fig. $7 \mathrm{~A}$, second trace, solid arrow). These changes were reversed upon rewarming. When the membrane potential was varied with DC current, the early IPSP (measured at a latency of $50 \mathrm{msec}$ ) reversed polarity about 10 $\mathrm{mV}$ negative to resting $V_{m}$ (mean $=-10.9 \pm 1.9 \mathrm{mV}$ at $37^{\circ} \mathrm{C} ; n=$ 5) (Fig. 7B). This apparent reversal potential agrees with previous measurements obtained for both the IPSP and $\gamma$-aminobutyric acid (GABA)-induced hyperpolarizations (Dingledine and Langmoen, 1980; Ben-Ari et al., 1981), and probably represents the $\mathrm{Cl}^{-}$equilibrium potential. The late hyperpolarizing potential (measured at a latency of $140 \mathrm{msec}$ ), however, reversed polarity at a significantly more negative potential (mean $=-16.3 \pm 3.5 \mathrm{mV}$ from resting $V_{m}$ $n=4, p<0.05$ ) (Fig. 7B). This suggests that the later hyperpolarizing potential is produced by an increase in a $\mathrm{K}^{+}$conductance (see also Nicoll and Alger, 1981b; Newberry and Nicoll, 1984). Late hyperpolarizing potentials were not apparent at $37^{\circ} \mathrm{C}$ and were observed in half of the population of cells recorded at $27^{\circ} \mathrm{C}$. Cooling did not affect the apparent reversal potential of the early IPSP (Fig. 7B).

\section{Discussion}

These data demonstrate that the membrane properties and synaptic responses of CA1b hippocampal pyramidal neurons are distinctly altered by reductions in temperature of only 5 to $10^{\circ}$ from normal body temperature. Cooling these neurons results in an increase in membrane $R_{N}$, slowing of action potential kinetics, an increase in the amplitude and duration of the $\mathrm{Ca}^{2+}$-activated $\mathrm{K}^{+}$ potential, and the appearance of a late hyperpolarizing synaptic potential. Some of these effects have been observed in other systems. Increases in $R_{N}$ with cooling have previously been reported for mammalian central neurons (Pierau et al., 1969; Scholfield, 1978; Halliwell and Adams, 1982). In molluscan neurons this increase in $R_{N}$ appears to be the result of a decrease in the resting sodium permeability (Marmor, 1971), a finding which is not inconsistent with our observations of increased apparent resistance at all $V_{m} s$. Changes in action potential parameters with cooling have been extensively described in a variety of preparations (Guttman, 1971; Klee et al., 1974; Joyner, 1981). As in those systems, the kinetics of ion channels underlying the action potential in hippocampal neurons appear to be slowed at low temperature, resulting in a reduction in the maximum rates of rise and fall of the action potential and an increase in its amplitude and duration. Estimates of temperature coefficients from our results are quite similar to previous measurements (e.g., Westerfield, et al., 1978) and confirm that cooling predominantly affects the falling phase of the action potential (Frankenhaeuser and Moore, 1963). The overall effect of these changes is to significantly broaden the action potential. Although EPSPS were not examined in this study, a broadening of action potentials most probably would increase evoked transmitter release.

The most striking findings of this study are the large increases in the amplitude and duration of the AHP which follows a train of action potentials, and the marked enhancement of spike frequency adaptation. These results indicate an increase in the $\mathrm{Ca}^{2+}$-activated $\mathrm{K}^{+}$ potential at low temperatures. Although the mechanisms which control the size of $\mathrm{Ca}^{2+}$-activated $\mathrm{K}^{+}$currents are not well understood, several possible mechanisms could account for this increase. The increase in the AHP could be an indirect result of an unchanged $\mathrm{K}^{+}$current flowing across the increased resistance of the membrane. This does not seem likely since large increases in the AHP were seen in cells which showed insignificant changes in input resistance. 

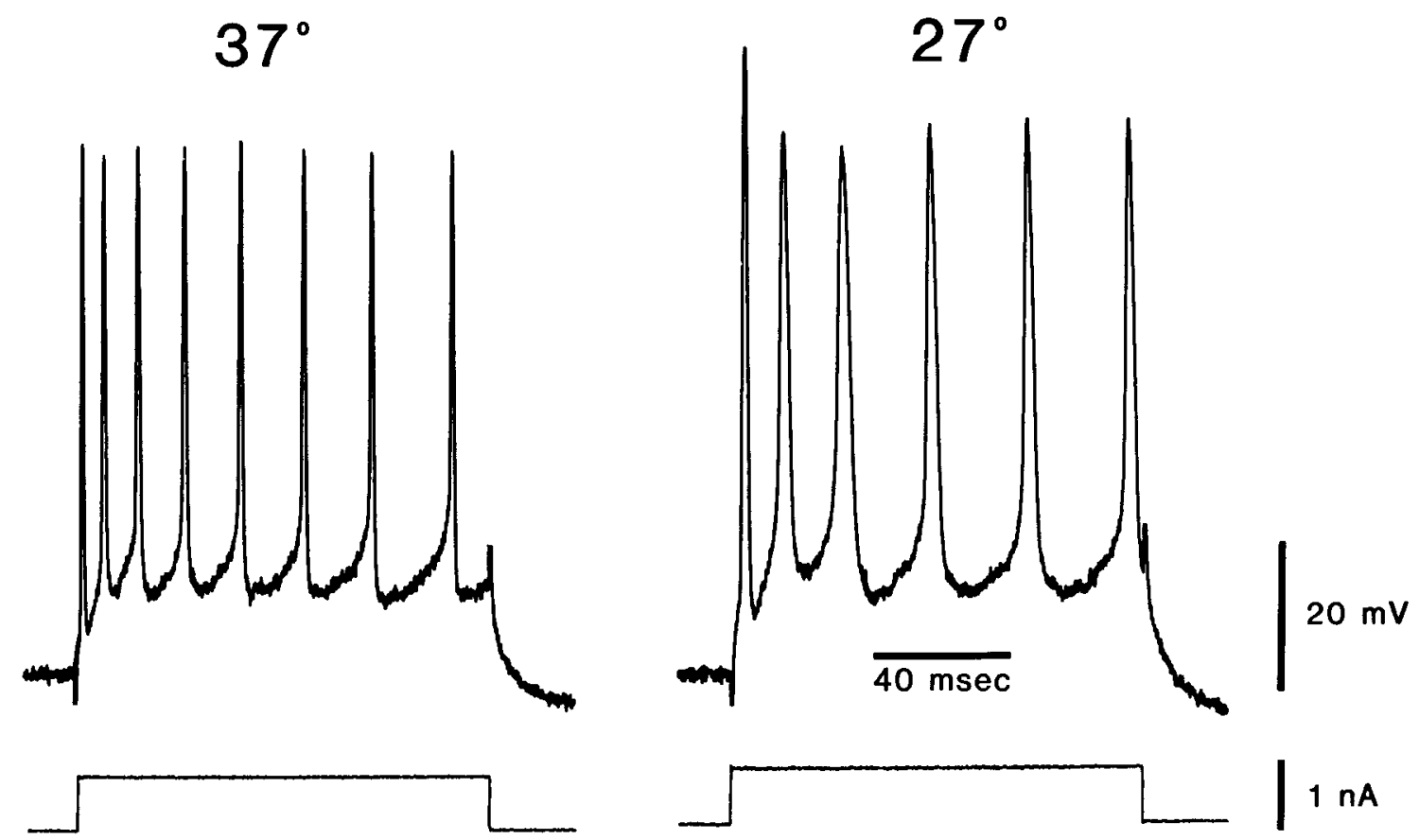

Figure 6. Effects of cooling on action potential amplitudes in a train of action potentials evoked by identical 120 -msec depolarizing pulses of $0.85 \mathrm{nA}$ Note the rapid decrement in action potential amplitude at $27^{\circ} \mathrm{C}$. DC current was used to return the cell to its original rest $V_{m}(-55 \mathrm{mV})$.

Figure 7. Effects of cooling on orthodromically evoked IPSPS in single cells. $A$, The peak amplitude of the IPSP was reduced by cooling and a late hyperpolarizing response became apparent (solid arrow). These changes were reversed upon rewarming. $B$, Reversal potentials of orthodromic IPSPs in a single cell at 37 and $27^{\circ} \mathrm{C}$. Sample traces at rest $V_{m}$ are shown superimposed in the inset. Reversal potentials of the IPSP have been plotted for two latencies, 50 and 140 msec after stimulation (arrows in inset). The apparent reversal potential of the early IPSP was $-9.2 \mathrm{mV}$ from rest at $37^{\circ} \mathrm{C}$ and $-7.3 \mathrm{mV}$ at $27^{\circ} \mathrm{C}$; however, the late hyperpolarizing potential reversed at -6 $\mathrm{mV}$ at $37^{\circ} \mathrm{C}$ but $-12.7 \mathrm{mV}$ at $27^{\circ} \mathrm{C}$. This suggests that, at $37^{\circ} \mathrm{C}$, the entire IPSP reverses at $\mathrm{E}_{\mathrm{Cl}}$ whereas, at low temperature, the late hyperpolarizing potential reverses at $E_{k}$. This cell did not show a reduction in the early IPSP amplitude. Rest $V_{m}=-70 \mathrm{mV}$. Lines were drawn by the least squares linear regression method. Calibration for the inset is the same as in A. Action potentials were amputated due to high gain.
A
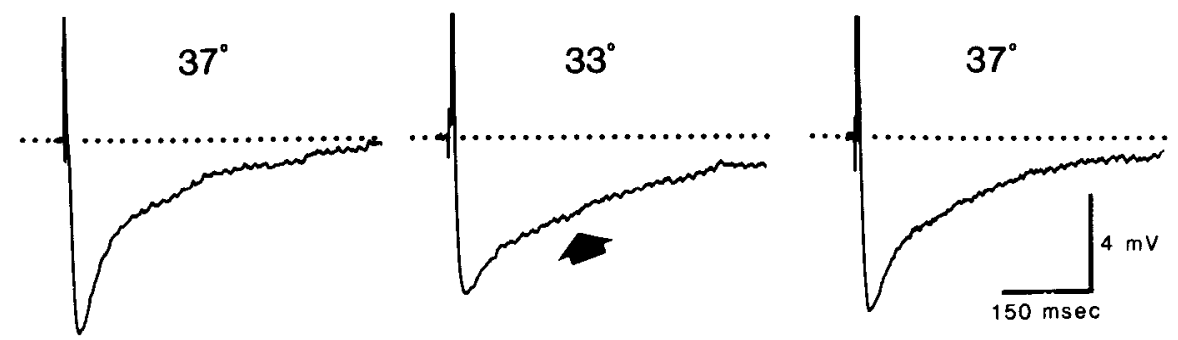

B

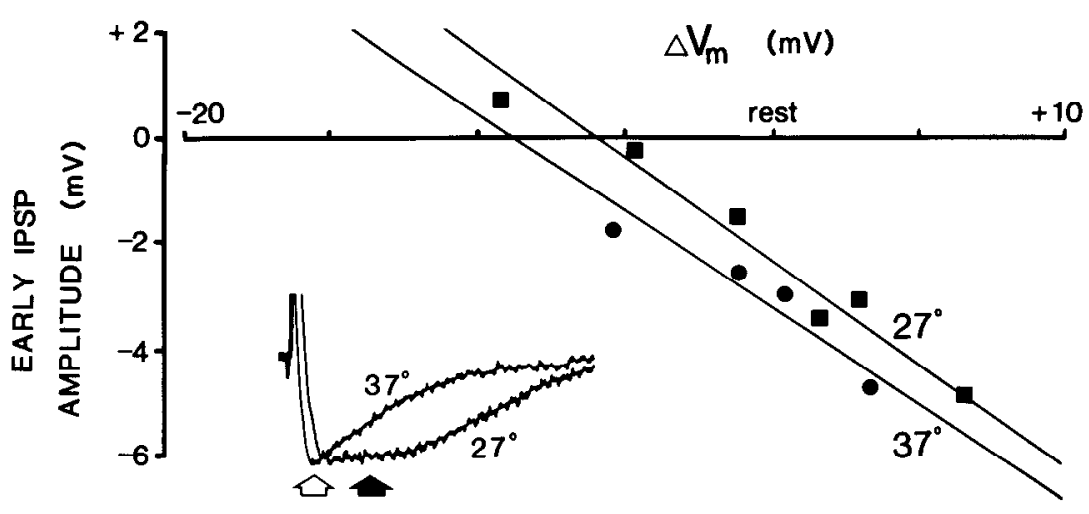

$\Delta V_{m}(m V)$

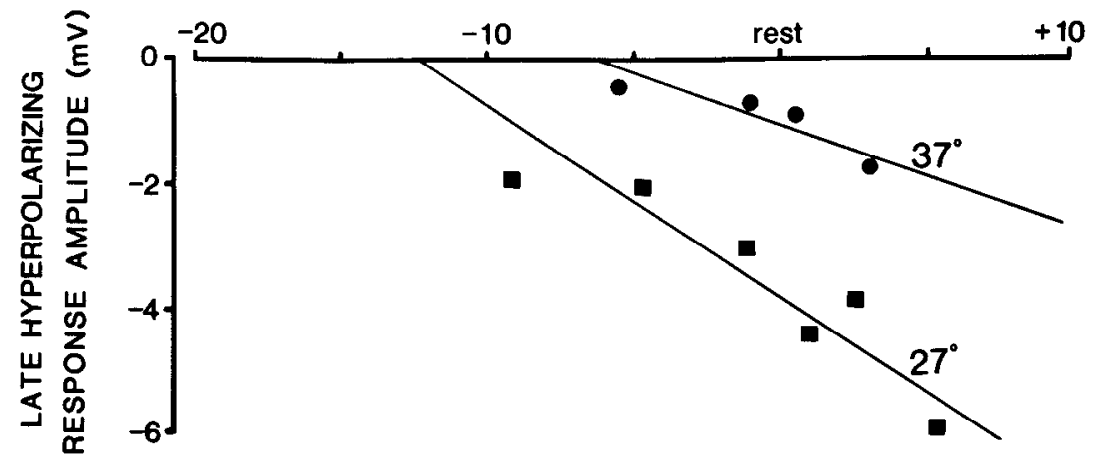


It has been shown that peak $\mathrm{Ca}^{2+}$-activated potassium current increases linearly with increased $\mathrm{Ca}^{2+}$ entry for Aplysia neurons (Gorman and Thomas, 1980). The increase in the peak amplitude of the AHP may, therefore, result from an increase in $\mathrm{Ca}^{2+}$ entry due to broadening of action potentials (see Fig. 6) and slowing of voltagedependent $\mathrm{Ca}^{2+}$ channel kinetics (Cota et al., 1983). However, an increase in $\mathrm{Ca}^{2+}$ entry is insufficient to explain the reduced rate of decay of equal amplitude AHPs (Fig. 4C). Cooling, therefore, must also be affecting some process subsequent to the entry of $\mathrm{Ca}^{2+}$, which results in prolongation of the AHP.

A probable explanation for these data is that the intracellular $\mathrm{Ca}^{2+}$ buffering ability of the neuron is slowed or reduced at low temperature. The termination of the AHP and other $\mathrm{Ca}^{2+}$-dependent events probably involves several processes which together remove $\mathrm{Ca}^{2+}$ from active sites on the interior of the cell membrane. Many of these processes are dependent on maintenance of the sodium gradient (Blaustein, 1974). In other preparations, manipulations which in crease internal $\mathrm{Na}^{+}$secondarily increase $\mathrm{Ca}^{2+}$-dependent phenomena (e.g., Rahamimoff et al., 1980; Sorimachi, 1983). Cooling has been shown to greatly reduce the activity of the $\mathrm{Na}^{+}-\mathrm{K}^{+}$pump in many preparations (e.g., den Hertog and Ritchie, 1969), including these neurons (Thompson and Prince, 1983), which may lead to an accumulation of $\mathrm{Na}^{+}$inside the cell (Cooke and Robinson, 1971). This could reduce $\mathrm{Na}^{+} / \mathrm{Ca}^{2+}$ exchange across the cell membrane and into intracellular organelles and thus impair $\mathrm{Ca}^{2+}$ buffering (Gustafson and Wigstrom, 1983). In support of this hypothesis, application of strophanthidin, a specific $\mathrm{Na}^{+}-\mathrm{K}^{+}$-ATPase inhibitor, also results in prolongation of the AHP in these neurons (S. M. Thompson and D. A. Prince, manuscript in preparation). This effect would thus be analogous to the well known inotropic action of cardiac glycosides on heart muscle (Lee and Klaus, 1971; Wier and Hess, 1984). A similar mechanism has been postulated for temperature effects on $\mathrm{Ca}^{2+}$-activated potassium current in Aplysia neurons (Johnston, 1980).

Synaptic potentials are also distinctly altered by cooling. The early, GABA-mediated, $\mathrm{Cl}^{-}$-dependent IPSP appeared to be reduced and a late hyperpolarizing synaptic potential, possibly produced by a $\mathrm{K}^{+}$conductance, became apparent. The lack of such a later hyperpolarizing synaptic potential in CA1 neurons in vivo (Andersen et al., 1964; Ben-Ari et al., 1981) and in vitro at $37^{\circ} \mathrm{C}$ suggests that it may be an artifact of reduced temperature. The concomitant increase in the AHP and appcarance of this latc hyperpolarizing potential suggests that they may share the same underlying mechanism. At $37^{\circ} \mathrm{C}$, synaptic excitation of CA1 pyramidal neurons does not elicit a significant $\mathrm{Ca}^{2+}$-activated $\mathrm{K}^{+}$conductance (Masukawa and Prince, 1984), yet at low temperature, with $\mathrm{Ca}^{2+}$ buffering apparently impaired, $\mathrm{Ca}^{2+}$ entry during synaptic activation may be sufficient to do so. However, recent evidence has suggested that the late hyperpolarizing potential is mediated by a potassium current which is not dependent on $\mathrm{Ca}^{2+}$ influx but may be directly evoked by GABA or some as yet unknown neurotransmitter (Blaxter et al., 1984; Lancaster and Wheal, 1984; Newberry and Nicoll, 1984). It should be noted that previous evidence for synaptic activation of a slow $\mathrm{K}^{+}$conductance in these neurons was obtained at low temperature (Nicoll and Alger, 1981b; Lancaster and Wheal, 1984; Newberry and Nicoll, 1984). It is not clear whether the reduction in the early IPSP represents a reduction of inhibitory transmitter release or, rather, "contamination" with an enhanced EPSP due to spike broadening.

We have shown that several responses and electrical characteristics of CA1 hippocampal pyramidal neurons are highly temperature dependent and may be qualitatively altered by a 5 to $10^{\circ} \mathrm{C}$ decrease in temperature. In particular, the importance of intracellular $\mathrm{Ca}^{2+}$ as a "regulator" of many cellular processes suggests that impairment of neuronal $\mathrm{Ca}^{2+}$ buffering may significantly change cellular physiology at low temperature. Temperature should therefore be considered an important parameter in the interpretation of data taken from brain slice tissue.

\section{References}

Alger, B. E., and R. A. Nicoll (1980) Epileptiform burst afterhyperpolarization: Calcium-dependent potassium potential in hippocampal CA1 pyramidal cells. Science 210: 1122-1124.

Alger, B. E., S. S. Dhanjal, R. Dingledine, S. Garthwaite, G. Henderson, G. L. King, P. Lipton, A. North, P. A. Schwartzkroin, T. A. Sears, M. Segal, T. S. Whittingham, and J. Williams (1984) Brain slice methods. In Brain Slices, R. Dingledine, ed., pp. 381-437, Plenum Publishing Corp., New York.

Andersen, P., J. C. Eccles, and Y. Loyning (1964) Pathway of postsynaptic inhibition in the hippocampus. J. Neurophysiol. 27: 608-619.

Ben-Ari, Y., K. Krnjevic, R. J. Reiffenstein, and W. Reinhardt (1981) Inhibitory conductance changes and action of $\gamma$-aminobutyrate in rat hippocampus. Neuroscience 6: 2445-2463.

Blaustein, M. P. (1974) The interrelationship between sodium and calcium fluxes across cell membranes. Rev. Physiol. Biochem. Pharmacol. 70: 3382.

Blaxter, T. J., M. F. Davies, P. L. Carlen, and N. Gurevitch (1984) GABA mediates a calcium-dependent potassium conductance in hippocampal CA1 pyramidal cells. Soc. Neurosci. Abstr. 10: 203.

Cooke, W. J., and J. D. Robinson (1971) Factors influencing calcium movements in rat brain slices. Am. J. Physiol. 221: 218-225.

Cota, G., L. N. Siri, and E. Stefani (1983) Calcium-channel gating in frog skeletal muscle membrane: Effect of temperature. J. Physio!. (Lond.) 338: 395-412.

den Hertog. A., and J. M. Ritchie (1969) A comparison of the effect of temperature, metabolic inhibitors, and of ouabain on the electrogenic component of the sodium pump in mammalian non-myelinated nerve fibres. J. Physiol. (Lond.) 204: 523-538.

Dingledine, R., and I. A. Langmoen (1980) Conductance changes and inhibitory actions of hippocampal recurrent IPSPs. Brain Res. 185: 277287.

Frankenhaeuser, B., and L. E. Moore (1963) The effect of temperature on the sodium and potassium permeability changes in myelinated nerve fibres of Xenopus laevis. J. Physiol. (Lond.) 169: 431-437.

Gorman, A. L. F., and M. V. Thomas (1980) Potassium conductance and internal calcium accumulation in a molluscan neurone. J. Physiol. (Lond.) 308: $287-313$.

Gustafsson, B., and H. Wigstrom (1983) Hyperpolarization following longlasting tetanic activation of hippocampal pyramidal cells. Brain Res. 275: 159-163.

Guttman, R. (1971) The effect of temperature on the function of excitable membranes. In Biophysics and Physiology of Excitable Membranes, W. J. Adelman, ed., pp. 320-336, Van Nostrand Reinhold Co., Now York.

Halliwell, J. V., and P. R. Adams (1982) Voltage-clamp analysis of muscarinic excitation in hippocampal neurons. Brain Res. 250: 71-92.

Hanvey, J. A., C. N. Scholfield, and D. A. Brown (1974) Evoked surfacepositive potentials in isolated mammalian olfactory cortex. Brain Res. 76 : 235-245.

Hodgkin, A. L., and A. F. Huxley (1952) A quantitative description of membrane current and its application to conduction and excitation in nerve. J. Physiol. (Lond.) 117: 500-544.

Hotson, J. R., and D. A. Prince (1980) A calcium-activated hyperpolarization follows repetitive firing in hippocampal neurons. J. Neurophysiol. 43: 409419.

Hotson, J. R., P. A. Schwartzkroin, and D. A. Prince (1977) Calcium activated after hyperpolarization in hippocampal slices maintained in vitro. Soc. Neurosci. Abstr. 3: 218.

Hotson, J. R., D. A. Prince, and P. A. Schwartzkroin (1979) Anomalous inward rectification in hippocampal neurons. J. Neurophysiol. 42: 889895.

Johnston, D. (1980) Voltage, temperature, and ionic dependence of the slow outward current in Aplysia burst-firing neurones. J. Physiol. (Lond.) 289. $145-157$.

Johnston, D., and T. H. Brown (1983) Interpretation of voltage-clamp measurements in hippocampal neurons. J. Neurophysiol. 50: 464-486.

Joyner, R. W. (1981) Temperature effects on neuronal elements. Fed. Proc. 40: $2814-2818$

Klee, M. R., F. K. Pierau, and D. S. Faber (1974) Temperature effects on resting potential and spike parameters of cat motoneurons. Exp. Brain Res. 19: 478-492.

Lancaster, B., and H. V. Wheal (1984) The synaptically evoked late hyperpolarization in hippocampal CA1 pyramidal cells is resistant to intracellular EGTA. Neuroscience 12: 267-275.

Lee, K. S., and W. Klaus (1971) The subcellular basis for the mechanism of inotropic action of cardiac glycosides. Pharmacol. Rev. 23: 193-261. 
824

Thompson et al.

Vol. 5, No. 3, Mar. 1985

Madison, D. V., and R. A. Nicoll (1982) Noradrenaline blocks accommodation of pyramidal cell discharge in the hippocampus. Nature 299: 636-638.

Marmor, M. F. (1971) The effects of temperature and ions on the currentvoltage relation and electrical characteristics of a molluscan neurons. $\mathrm{J}$. Physiol. (Lond.) 218: 573-598.

Masukawa, L. M., and D. A. Prince (1984) Synaptic control of excitability in isolated dendrites of hippocampal neurons. J. Neurosci. 4: 217-227.

Masukawa, L. M., S. M. Thompson, and D. A. Prince (1984) Decreases in temperature alter intrinsic and synaptic properties of hippocampal CA1 pyramidal cells. Soc. Neurosci. Abstr. 10: 6 .

Newberry, N. R., and R. A. Nicoll (1984) A bicuculline-resistant inhibitory postsynaptic potential in rat hippocampal pyramidal cells in vito. $\mathrm{J}$. Physiol. (Lond.) 348: 239-254.

Nicoll, R. A., and B. E. Alger (1981a) A simple chamber for recording from submerged brain slices. J. Neurosci. Methods 4: 153-156.

Nicoll, R. A., and B. E. Alger (1981b) Synaptic excitation may activate a calcium dependent potassium conductance in hippocampal pyramidal cells. Science 212: 957-959.

Pierau, F. K., M. R. Klee, and F. W. Klussmann (1969) Effects of local hypoand hyperthermia on mammalian spinal motoneurones. Fed. Proc. 28: 1006-1010.

Rahamimoff, R., A. Lev-Tov, and H. Meir (1980) Primary and secondary regulation of quintal transmitter release: Calcium and sodium. J. Exp. Biol. 89: 5-18.
Scholfield, C. N. (1978) Electrical properties of neurons in the olfactory cortex slice in vito. J. Physiol. (Lond.) 275: 535-546.

Schwartzkroin, P. A. (1975) Characteristics of CA1 neurons recorded intracellularly in the hippocampal in vito slice preparation. Brain Res. 85: 423436.

Schwartzkroin, P. A. (1977) Further characteristics of hippocampal CA1 cells in vito. Brain Res. 128: 53-68.

Schwartzkroin, P. A. and C. E. Stafstrom (1980) Effects of EGTA on the calcium-activated hyperpolarization in hippocampal CA3 pyramidal cells. Science 210: 1125-1126.

Sorimachi, M. (1983) Inhibition of Na pumps enhances Ca-dependent release of vasopressin from the isolated neurohypophysis of the rat. Jpn. J. Physiol. 33: $1061-1066$.

Spencer, W. A., and E. R. Kandel (1961) Electrophysiology of hippocampal neurons. III. Firing level and time constant. J. Neurophysiol. 24: 260-271.

Thompson, S. M., and D. A. Prince (1983) Activation of an electrogenic sodium pump in hippocampal pyramidal neurons. Soc. Neurosci. Abstr. 9: 735.

Westerfield, M., R. W. Joyner, and J. W. Moore (1978) Temperature-sensitive conduction failure at axon branch points. J. Neurophysiol. 41: 1-8.

Weer, W. G., and P. Hess (1984) Excitation-contraction coupling in cardiac Purkinje fibers. Effects of cardiotonic steroids on the intracellular $\left[\mathrm{Ca}^{++}\right]$ transient, membrane potential, and contraction. J. Gen. Physiol. 83: 395415. 